\title{
Protein N-terminal acetylation: NAT 2007-2008 Symposia
} Thomas Arnesen1,2,3

Address: ${ }^{1}$ Department of Molecular Biology, University of Bergen, N-5020 Bergen, Norway, ${ }^{2}$ Department of Surgical Sciences, University of Bergen, N-5020 Bergen, Norway and ${ }^{3}$ Department of Surgery, Haukeland University Hospital, N-5021 Bergen, Norway

Email: Thomas Arnesen - thomas.arnesen@mbi.uib.no

from NAT 2007 and 2008 Symposia: Protein N-terminal Acetylation and Protein N-terminal Acetyltransferases (NATs)

Bergen, Norway. 24-25 May 2007 and II-13 September 2008

Published: 4 August 2009

BMC Proceedings 2009, 3(Suppl 6):SI doi:10.1186/1753-656I-3-S6-SI

This article is available from: http://www.biomedcentral.com/I753-656I/3/S6/SI

(c) 2009 Arnesen; licensee BioMed Central Ltd.

This is an open access article distributed under the terms of the Creative Commons Attribution License (http://creativecommons.org/licenses/by/2.0), which permits unrestricted use, distribution, and reproduction in any medium, provided the original work is properly cited.

\begin{abstract}
Protein $\mathrm{N}$-terminal acetylation is a very common modification, but has during the past decades received relatively little attention. In order to put this neglected field back on the scientific map, we have in May 2007 and September 2008 arranged two international NAT symposia in Bergen, Norway. This supplement contains selected proceedings from these symposia reflecting the current status of the field, including an overview of protein $\mathrm{N}$-terminal acetylation in yeast and humans, a novel nomenclature system for the $\mathrm{N}$-terminal acetyltransferases (NATs) and methods for studying protein $\mathrm{N}$-terminal acetylation in vitro and in vivo.
\end{abstract}

\section{Introduction}

More than 50 years ago, the first $\mathrm{N}^{\alpha}$-terminally acetylated protein was discovered [1]. Since then, numerous proteins carrying this modification have been reported, and it has become evident that protein $\mathrm{N}^{\alpha}$-terminal acetylation is a major modification in eukaryotic cells. In the 1970s, work from Brown indicated that approximately $80 \%$ of the soluble proteins from mammalian cells were $\mathrm{N}^{\alpha}$-terminally acetylated $[2,3]$. In the same period, the basic concepts of $\mathrm{N}^{\alpha}$-terminal acetylation were revealed. Strous and Bloemendal demonstrated that this type of acetylation was a co-translational phenomenon, occurring on nascent polypeptide chains. $\mathrm{N}^{\alpha}$-terminal acetylation occurred in an in vitro cell free system, when about 25-50 amino acid residues protruded from the ribosome $[4,5]$. In parallel, Pestana and Pitot presented data supporting the same model $[6,7]$. Their results strongly indicated that this reaction was catalyzed by enzyme(s) physically associated to the ribosomes and furthermore suggested that $\mathrm{N}$-terminal acetylation occurs on polypeptides $40-70$ amino acid residues in length.

The actual identification of the N-terminal acetyltransferases (NATs) came many years later. The yeast NatA complex, a major NAT composed of the catalytic subunit Naa10p (Ard1p) and the auxiliary subunit Naa15p (Nat1p), was identified in 1989 by the joint efforts of Sternglanz, Sherman, Grunstein and coworkers [8], and further as a physical complex in 1992 by Park and Szostak [9]. Then, Naa30p (Mak3p) [10] and Naa20p (Nat3p) [11] were identified as additional NATs with specific substrate specificities. In 1999, Sherman, Blomberg and coworkers introduced the NAT type classification based on the ability of the different NATs to acetylate different substrates: NatA (Naa10p-Naa15p), NatB (Naa20p) and NatC (Naa30p) [11]. Later, the auxiliary subunits of the NatB (Naa25p/Mdm20p) and NatC (Naa35p/Mak10p and Naa38p/Mak31p) complexes were identified by 
Polevoda and Sherman $[12,13]$ and by Singer and Shaw (NatB) [14]. In 2003, an additional enzyme was discovered, Naa40p (Nat4p), making a new NAT type: NatD [15]. The same year, Rospert and co-workers provided a mechanistic insight of the NatA complex, revealing that the Naa15p subunit anchors the NatA complex to the ribosome and the nascent polypeptide, and that a potential fifth NAT, Naa50p (Nat5p), is physically associated with Naa10p and Naa15p [16]. NATs from higher eukaryotes have recently been identified $[17,18]$ and between 2005 and 2009, all major human N-terminal acetyltransferases, NatA, NatB and NatC, were characterized [19-23]. Finally, large scale targeted proteomics has now made it possible to quantitatively analyse protein $\mathrm{N}$-terminal acetylation on hundreds of unique proteins from a biological sample. Work by Arnesen and Van Damme et al., has revealed the conservation of substrate specificity of the NatA complex from yeast to humans, and also provided more accurate determinations of $\mathrm{N}$-terminal acetylation patterns [24].

Despite some very good examples describing the importance of $\mathrm{N}$-terminal acetylation at the substrate level $[10,13,14,25-29]$, the overall importance of $\mathrm{N}$-terminal acetylation remains unknown and represent an important future challenge.

Furthermore, in higher eukaryotes there might be more NATs to be discovered and there are several distinct substrate types that are acetylated by so far unknown NATs.

\section{Summary of the supplement}

The NAT field has only had a few dedicated groups primarily focusing on N-terminal acetylation and NATs, and there is currently no scientific community specifically focusing on this field, despite the fact that it is one of the most common protein modifications, and knockout/ knockdown phenotypes of NATs suggest very important functional aspects. In order to contribute to the promotion and activation of this field, we have in 2007 and 2008 arranged two symposia in Bergen, Norway. This supplement contains selected proceedings from some of the symposia participants.

An issue of importance, and discussed at these meetings, is the nomenclature of the NAT enzymes. For many reasons, including significant confusion from the non specialist scientists, all participants agreed that a novel nomenclature system for the NATs should be developed by the Sherman lab. After a round of approval among scientists in the field around the world, the new nomenclature is presented here by Polevoda et al. [30].

The human NATs have recently been discovered and several presentations from the group of Varhaug and Lille- haug were made at the symposia. Here, Gromyko and Starheim et al. have made a review of the human NATs, composition and biological significance to summarize the current knowledge of the human NATs both from their own group, but also recent results from several other research groups [31].

The next paper by Ametzazurra et al., describes the human NatB, which along with two previous papers $[22,32]$ identifies this human complex composed of the catalytic subunit hNaa20p (hNat3) and the auxiliary subunit hNaa25p (hMdm20). The importance of the hNatB complex is stressed by the significant phenotypes associated with its knockdown [19].

In order to study N-terminal acetylation, it is of vital importance to have appropriate methodology available. Evjenth $e t$ al. describes a reliable assay for the determination of in vitro $\mathrm{N}$-terminal acetylation, including substrate specificity and enzymatic parameters [33].

In the final paper, Van Damme et al. present a robust and sensitive method for assessing the N-terminal acetylation status of proteins in vivo [34]. The method is based on in vitro modifications of the protein $\mathrm{N}$-termini, Cofractional Diagonal Chromatography (COFRADIC) [35] and finally Mass Spectrometry analysis. The proof of principle was very recently demonstrated in a large scale analysis of more than 1000 unique yeast and human proteins [24]. Clearly, this and similar methodologies will be crucial for the in depth studies that will be pursued in the next years.

\section{Competing interests}

The author declares that he has no competing interests.

\section{Acknowledgements}

The Norwegian Research Council is acknowledged for financially supporting these symposia (grant 180598 to TA). The Department of Molecular Biology, University of Bergen, is thanked for hosting the events. In particular members of the group of Professor Johan R. Lillehaug and Professor Jan Erik Varhaug are thanked for valuable assistance. Reviewers are thanked for evaluating the Proceedings. Finally, all symposia participants and Proceedings authors are thanked for their contribution and enthusiasm.

This article has been published as part of BMC Proceedings Volume 3 Supplement 6, 2009: Proceedings of the 2007 and 2008 Symposia on Protein $\mathrm{N}$-terminal Acetylation. The full contents of the supplement are available online at http://www.biomedcentral.com//753-656I/3? issue $=\mathrm{S} 6$

\section{References}

I. Narita K: Isolation of acetylpeptide from enzymic digests of TMV-protein. Biochim Biophys Acta 1958, 28:184-191.

2. Brown JL, Roberts WK: Evidence that approximately eighty per cent of the soluble proteins from Ehrlich ascites cells are Nalpha-acetylated. J Biol Chem 1976, 25 I:1009-1014.

3. Brown JL: A comparison of the turnover of alpha- $N$ acetylated and nonacetylated mouse L-cell proteins. J Biol Chem 1979, 254: | 1447-| 449 . 
4. Strous G], van Westreenen H, Bloemendal H: Synthesis of lens protein in vitro. $\mathbf{N}$-terminal acetylation of alpha-crystallin. Eur J Biochem 1973, 38:79-85.

5. Strous GJ, Berns AJ, Bloemendal H: $\mathbf{N}$-terminal acetylation of the nascent chains of alpha-crystallin. Biochem Biophys Res Commun 1974, 58:876-884.

6. Pestana $\mathrm{A}$, Pitot $\mathrm{HC}: \mathbf{N}$-terminal acetylation of histone-like nascent peptides on rat liver polyribosomes in vitro. Nature 1974, 247:200-202.

7. Pestana A, Pitot HC: Acetylation of nascent polypeptide chains on rat liver polyribosomes in vivo and in vitro. Biochemistry | 1975, I 4: | 404-14|2.

8. Mullen JR, Kayne PS, Moerschell RP, Tsunasawa S, Gribskov M, Colavito-Shepanski M, et al: Identification and characterization of genes and mutants for an $\mathbf{N}$-terminal acetyltransferase from yeast. $E M B O J$ 1989, 8:2067-2075.

9. Park EC, Szostak JW: ARDI and NATI proteins form a complex that has $\mathbf{N}$-terminal acetyltransferase activity. EMBO J 1992, I I:2087-2093.

10. Tercero JC, Wickner RB: MAK3 encodes an $\mathbf{N}$-acetyltransferase whose modification of the L-A gag NH2 terminus is necessary for virus particle assembly. J Biol Chem 1992, 267:20277-2028I.

II. Polevoda B, Norbeck J, Takakura H, Blomberg A, Sherman F: Identification and specificities of $\mathbf{N}$-terminal acetyltransferases from Saccharomyces cerevisiae. EMBO J 1999, 18:6I55-6I68.

12. Polevoda B, Sherman F: NatC Nalpha-terminal acetyltransferase of yeast contains three subunits, Mak3p, MakI0p, and Mak3 Ip. J Biol Chem 200I, 276:20154-20I59.

13. Polevoda B, Cardillo TS, Doyle TC, Bedi GS, Sherman F: Nat3p and Mdm20p are required for function of yeast NatB Nalpha-terminal acetyltransferase and of actin and tropomyosin. J Biol Chem 2003, 278:30686-30697.

14. Singer JM, Shaw JM: Mdm20 protein functions with Nat3 protein to acetylate $\mathrm{TpmI}$ protein and regulate tropomyosinactin interactions in budding yeast. Proc Natl Acad Sci USA 2003, 100:7644-7649.

15. Song OK, Wang X, Waterborg JH, Sternglanz R: An Nalpha-acetyltransferase responsible for acetylation of the $\mathrm{N}$-terminal residues of histones H4 and H2A. I Biol Chem 2003, 278:38109-38II2.

16. Gautschi M, Just $S$, Mun A, Ross S, Rucknagel $P$, Dubaquie $Y$, et al.: The yeast N(alpha)-acetyltransferase NatA is quantitatively anchored to the ribosome and interacts with nascent polypeptides. Mol Cell Biol 2003, 23:7403-74I4.

17. Pesaresi P, Gardner NA, Masiero S, Dietzmann A, Eichacker L, Wickner $\mathrm{R}$, et al.: Cytoplasmic $\mathbf{N}$-terminal protein acetylation is required for efficient photosynthesis in Arabidopsis. Plant Cell 2003, I 5: 1817-1832.

18. Sugiura N, Adams SM, Corriveau RA: An evolutionarily conserved $\mathbf{N}$-terminal acetyltransferase complex associated with neuronal development. J Biol Chem 2003, 278:40I I 3-40I 20.

19. Ametzazurra A, Gázquez C, Lasa M, Larrea E, Prieto J, Aldabe R: Characterization of the human $\mathbf{N} \alpha$-terminal acetyltransferase B enzymatic complex. BMC Proc 2009, 3(Suppl 6):S4.

20. Arnesen T, Anderson D, Baldersheim C, Lanotte M, Varhaug JE, Lillehaug JR: Identification and characterization of the human ARDI-NATH protein acetyltransferase complex. Biochem J 2005, 386:433-443.

21. Arnesen T, Gromyko D, Pendino F, Ryningen A, Varhaug JE, Lillehaug JR: Induction of apoptosis in human cells by RNAi-mediated knockdown of hARDI and NATH, components of the protein N-alpha-acetyltransferase complex. Oncogene 2006, 25:4350-4360.

22. Starheim KK, Arnesen T, Gromyko D, Ryningen A, Varhaug JE, Lillehaug JR: Identification of the human N(alpha)-acetyltransferase complex B (hNatB): a complex important for cellcycle progression. Biochem J 2008, 4 I 5:325-331.

23. Starheim KK, Gromyko D, Evjenth R, Ryningen A, Varhaug JE, Lillehaug JR, et al.: Knockdown of the Human $\mathbf{N}$ \{alpha\}-Terminal Acetyltransferase Complex C (hNatC) Leads to p53Dependent Apoptosis and Aberrant hArl8b Localization. Mol Cell Biol 2009, 29:3569-358I.

24. Arnesen T, Van Damme P, Polevoda B, Helsens K, Evjenth R, Colaert $\mathrm{N}$, et al.: Proteomics analyses reveal the evolutionary conser- vation and divergence of $\mathrm{N}$-terminal acetyltransferases from yeast and humans. Proc Natl Acad Sci USA 2009, 106:8I57-8162.

25. Behnia R, Panic B, Whyte JR, Munro S: Targeting of the Arf-like GTPase Arl3p to the Golgi requires $\mathbf{N}$-terminal acetylation and the membrane protein Sys I p. Nat Cell Biol 2004, 6:405-4I3.

26. Caesar $R$, Blomberg $A$ : The stress-induced Tfs Ip requires NatB-mediated acetylation to inhibit carboxypeptidase $Y$ and to regulate the protein kinase A pathway. J Biol Chem 2004, 279:38532-38543.

27. Geissenhoner A, Weise C, Ehrenhofer-Murray AE: Dependence of ORC silencing function on NatA-mediated Nalpha acetylation in Saccharomyces cerevisiae. Mol Cell Biol 2004, 24: $10300-10312$

28. Setty SR, Strochlic TI, Tong AH, Boone C, Burd CG: Golgi targeting of ARF-like GTPase Arl3p requires its Nalpha-acetylation and the integral membrane protein Syslp. Nat Cell Biol 2004, 6:4|4-4|9.

29. Wang X, Connelly JJ, Wang CL, Sternglanz R: Importance of the Sir3 $\mathbf{N}$ terminus and its acetylation for yeast transcriptional silencing. Genetics 2004, 168:547-55।.

30. Polevoda B, Arnesen T, Sherman F: A synopsis of eukaryotic N $\alpha$ terminal acetyltransferases: nomenclature, subunits and substrates. BMC Procedings 2009, 3(Suppl 6):S2.

3I. Gromyko D, Starheim KK, Velde R, Varhaug JE, Arnesen T: Composition and biological significance of the human $\mathbf{N} \alpha$-terminal acetyltransferases. BMC Proceedings 2009, 3(Suppl 6):S3.

32. Ametzazurra A, Larrea E, Civeira MP, Prieto J, Aldabe R: Implication of human $\mathbf{N}$-alpha-acetyltransferase $\mathbf{5}$ in cellular proliferation and carcinogenesis. Oncogene 2008, 27:7296-7306.

33. Evjenth R, Hole K, Ziegler M, Lillehaug JR: Application of reversephase HPLC to quantify oligopeptide acetylation eliminates interference from unspecific acetyl CoA hydrolysis. BMC Proceedings 2009, 3(Suppl 6):S5.

34. Van Damme P, Van Damme J, Demol H, Staes A, Vandekerckhove J, Gevaert K: A review of COFRADIC techniques targeting protein N-terminal acetylation. BMC Proceedings 2009, 3(Suppl 6):S6.

35. Gevaert K, Goethals M, Martens L, Van Damme J, Staes A, Thomas $\mathrm{GR}$, et al:: Exploring proteomes and analyzing protein processing by mass spectrometric identification of sorted $\mathbf{N}$ terminal peptides. Nat Biotechnol 2003, 21 :566-569.

Publish with Bio Med Central and every scientist can read your work free of charge

"BioMed Central will be the most significant development for disseminating the results of biomedical research in our lifetime. "

Sir Paul Nurse, Cancer Research UK

Your research papers will be:

- available free of charge to the entire biomedical community

- peer reviewed and published immediately upon acceptance

- cited in PubMed and archived on PubMed Central

- yours - you keep the copyright 